\title{
IbM INDUSTRI RUMAH TANGGA AYAM UNGKEP DI GEMBONGAN, KECAMATAN KARTASURA, KABUPATEN SUKOHARJO
}

\author{
Siswanti, R. Baskara Katri Anandito, Dian Rachmawanti Affandi \\ Program Studi Ilmu dan Teknologi Pangan, Fakultas Pertania, Universitas Sebelas Maret \\ E-mail: siswanti@staff.uns.ac.id
}

\begin{abstract}
Household industry Ayam Ungkep "Mas Haji” is located in Gembongan Village, Kartasura SubDistrict, Sukoharjo Regency. The problems faced by household industry ayam ungkep in Gembongan Village are production capacity issues are still small, the packaging is not yet appropriate, does not have nutrition fact, and the difficulty of marketing the resulting product. The solutions offered by the community devotion team are through the following activities such as: (1) The introduction of appropriate technology for the processing of ayam ungkep by chicken feathering machine and freezer; (2) the introduction of packaging technology with vacuum sealer and material variation packaging; (3) testing of nutritional composition of the product; and (4) IT-based marketing training and direct selling strategies. All the programs in this devotion activity have been done well and smoothly. Introduction of chicken feathering machine and freezer can increase production capacity in partner I and storage of ayam ungkep at partner II. Vacuum sealer and varieties of packaging of ayam ungkep can improve packaging efficiency and increase the consumer. IT-based marketing training and direct selling strategies can increase the product sales capacity until $35 \%$.
\end{abstract}

Keywords: Ayam ungkep "Mas Haji", Gembongan Village

\section{PENDAHULUAN}

Kecamatan Kartosuro berlokasi di Kabupaten Sukoharjo yang memiliki banyak sentra industri rumah tangga. Tercatat terdapat sedikitnya 27.878 usaha kecil dan rumah tangga yang bergerak dalam berbagai bidang (Sukoharjo dalam angka, 2016). Salah satu industri rumah tangga yang mulai banyak dilakukan masyarakat adalah pengolahan ayam. Ayam, salah satu sumber protein hewani yang menjadi favorit di masyarakat. Hal ini didukung karena cukup banyaknya peternakan ayam baik ayam boiler maupun ayam kampung. Salah satunya adalah peternakan Bapak Hartanto. Peternakan ini sudah dirintis sejak tahun 2012. Sampai saat ini telah terdapat setidaknya 16.000 ayam boiler yang dikelola di berbagai tempat. Dari ternak ayam boiler, usaha ini merambah ke usaha peternakan ayam kampung.

Usaha ternak ayam kampung dipilih karena memiliki kelebihan daya adaptasi terhadap lingkungan serta kecepatan menghasilkan dari segi permodalan yang lebih baik serta pemeliharaan yang lebih mudah dibandingkan usaha ternak yang lain. Dari segi kualitas daging, ayam kampung juga memiliki kelebihan dibandingkan ayam boiler yaitu memiliki nilai gizi yang lebih tinggi, lebih rendah kolesterol, serta rasa yang lebih gurih dan aroma yang lebih nikmat (Murtidjo, 1994). Keunggulan inilah yang menyebabkan olahan makanan dari ayam kampung lebih diminati masyarakat.

Dalam usaha yang dilakukan mitra, berbeda dengan ternak ayam boiler yang banyak hanya dijual hidup, ayam kampung yang dikelola ini terlebih dahulu diolah 
menjadi makanan olahan. Salah satu makanan olahan dari ayam kampung yang telah diusahakan adalah ayam ungkep. Tehnik mengungkep adalah budaya memasak khas nusantara yang sudah dipraktekkan sejak lama. Ungkep sendiri adalah bahasa Jawa yang bermakna memasak bahan makanan sudah dengan bumbu di atas api kecil dalam waktu yang lebih lama. Bahan makanan mentah, seperti daging ayam atau daging sapi tidak hanya dimarinasi dengan bumbu dan didiamkan lama, melainkan melalui proses pemasakan. Dengan diungkep, bumbu mudah melepaskan enzim yang dapat mengeluarkan aroma khas. Sehingga menghasilkan cita rasa yang eksotis dan mengundang selera untuk disantap.

Usaha ayam ungkep yang dilakukan mitra ini telah dimulai 1 tahun yang lalu, namun baru memiliki kapasitas produksi mencapai 25 ekor setiap minggunya. Kapasitas produksi ini belum memenuhi jumlah permintaan yang ada. Permintaan konsumen bisa mencapai $3 \mathrm{x}$ lipat dari persediaan. Pemasaran yang dilakukan juga masih dalam lingkup wilayah terbatas. Secara umum masalah yang terjadi pada industri rumah tangga (IRT) mitra ini antara lain: (1) kondisi usaha yang stagnan karena peralatan yang digunakan masih terbatas dan sederhana sehingga kapasitas produksi maupun penyimpanan minimal, (2) pengemasan produk yang kurang baik dan menarik, (3) belum adanya pengujian komposisi nutrisi produk, serta (4) teknik penjualan yang masih sederhana sehingga tidak berkembangnya daerah pemasaran.

Sebagai upaya untuk menyelesaikan masalah tersebut, tim pengabdian UNS telah bersepakat dengan industri rumah tangga mitra untuk menyelenggarakan program (1) Introduksi teknologi tepat guna proses pengolahan ayam ungkep berupa mesin pencambut bulu ayam dan freezer; (2) Introduksi teknologi pengemasan dengan vacuum sealer dan variasi bahan pengemas; (3)
Pengujian komposisi nutrisi produk; dan (4) Pelatihan pemasaran berbasis TI dan strategi direct selling. Hal tersebut telah dituangan dalam surat perjanjian. Tujuan pengabdian ini adalah: (1) meningkatkan kapasitas produksi dan penyimpanan ayam ungkep melalui introduksi mesin pencabut bulu ayam dan freezer, (2) meningkatkan efisiensi pengemasan dengan vacuum sealer dan variasi bahan pengemas ayam ungkep yang dihasilkan, (3) melakukan pengujian komposisi nutrisi produk, dan (4) memberikan pelatihan pemasaran ayam berbasis TI dan strategi direct selling.

\section{METODE}

Kegiatan pengabdian IbM ini dilaksanakan pada bulan Juli 2017 di Desa Gembongan, Kecamatan Kartosuro, Kabupaten Sukoharjo. Solusi yang ditawarkan untuk mengatasi permasalahanpermasalahan yang dihadapi mitra adalah sebagai berikut:

\section{Introduksi teknologi tepat guna proses pengolahan dan penyimpanan ayam ungkep berupa mesin pencabut bulu ayam dan freezer}

Pengolahan ayam kampung menjadi ayam ungkep sebenarnya cukup sederhana. Proses diawali dari penyembelihan, pencabutan bulu, pemotongan ayam, pemasakan dengan teknik ungkep, pengemasan, dan penyimpanan. Pada mitra, proses awal yang menjadi kendala adalah proses pencabutan bulu ayam. Proses ini masih dilakukan secara manual. Hal inilah yang menyebabkan proses di bagian awal ini membutuhkan waktu yang cukup lama. Untuk mencabut bulu ayam 1 ekor membutuhkan waktu sekitar 20 menit. Hal ini disebabkan karena ayam kampung memiliki bulu yang lebih banyak dan kaku dibandingkan ayam boiler. Disamping itu pencabutan bulu dilakukan setelah ayam yang telah disembelih direndam beberapa 
saat dalam air panas. Sehingga proses pencabutan secara manual harus perlahan dan hati-hati agar tidak melukai tangan.

Proses lain yang menjadi kendala dalam pengolahan ayam ungkep adalah penyimpanan. Ayam ungkep yang dihasilkan, dituntut untuk disimpan beku agar produk memiliki umur simpan yang lebih lama. Pada mitra, frezer yang dimiliki masih sangat kecil dan dipakai bersamaan untuk menyimpan produk lain sehingga kapasitas penyimpanan ayam ungkep sangat terbatas.

Proses yang lama dalam pencabutan bulu ayam, serta kapasitas freezer yang masih kecil, menyebabkan IRT ayam ungkep ini belum mampu menambah kapasitas produksi ayam ungkep yang dihasilkan. Sehingga untuk mengatasi hal tersebut, tim pengabdian sepakat untuk memberikan bantuan dengan mengintroduksikan mesin pencabut bulu ayam dan freezer kepada mitra. Mesin pencabut bulu ayam memiliki kelebihan yaitu mampu menghemat waktu karena dapat mencabut bulu ayam sampai 4 ekor sekaligus dalam waktu 5-10 menit. Selain itu produk yang dihasilkan lebih bersih dan higienis. Pemberian freezer dalam kapasitas yang lebih besar diharapkan agar mitra mampu memproduksi ayam ungkep yang lebih banyak karena tidak khawatir lagi masalah penyimpanan.

\section{Perbaikan pengemasan produk dengan vacuum sealer dan variasi bahan pengemas}

Proses yang juga penting dalam pembuatan ayam ungkep adalah pengemasan. Pada produk ini pengemasan harus dilakukan secara vakum, agar produk memiliki umur simpan yang lebih lama. Menurut Syarief dan Hlid (1993), pengemasan vakum pada prinsipnya adalah pengeluaran gas dan uap air dari produk yang dikemas, sedangkan pengemasan non vakum dilakukan tanpa mengeluarkan gas dan uap air yang terdapat dalam produk. Oleh karena itu pengemasan vakum cenderung menekan jumlah bakteri, perubahan bau, rasa, serta penampakan selama penyimpanan, karena pada kondisi vakum, bakteri aerob yang tumbuh jumlahnya relatif lebih kecil dibanding dalam kondisi tidak vakum. Pengemasan vakum sangat berfungsi dan yang paling diperhatikan dalam industri kemasan produk makanan karena tanpa adanya proses vakum akan mempengaruhi rasa, bau dan tekstur dari makanan tersebut. Selain itu juga akan mencegah timbulnya berbagai macam bakteri yang akan tumbuh di dalam isi kemasan, dikarenakan bakteri tidak akan bisa berkembang jika tidak adanya kadar oksigen. Hal ini membuat makanan yang terletak didalam kemasan produk akan tetap terjaga kehigienisannya dan membuat makanan jadi bisa bertahan dalam waktu yang sudah ditentukan.

Akan tetapi, untuk memperoleh hasil pengemasan produk yang benar-benar vakum ternyata tidak mudah. Penggunaan alat serta bahan pengemas (plastik) yang tidak tepat dapat menyebabkan kegagalan pengemasan. Hal ini yang sering terjadi kepada mitra. Peralatan vacuum sealer yang dimiliki mitra saat ini masih berkapasitas kecil dan berkemampuan menciptakan vakum yang rendah. Tidak jarang produk yang telah di vakum kembali menjadi sobek atau bocor. Hal ini tentu saja menyebabkan banyak kerugian.

Variasi dalam penggunaan bahan pengemas produk ayam ungkep selain berfungsi meningkatkan ketahanan produk dari kerusakan, juga untuk meningkatkan nilai jual produk. Pengemasan yang dilakukan saat ini hanya menggunakan plastik untuk membungkus ayam ungkep tanpa adanya label produk. Dalam program ini selain diintroduksikan mesin pengemas vakum dengan kapasitas yang lebih besar, juga akan didesaignkan label produk agar tampilan produk lebih menarik. 
Variasi bahan pengemas yang akan diintroduksikan adalah penggunaan plastik serta alumunium foil untuk kemasan primer disertai dengan label produk. Bentuk dan design pengemasan yang unik dan menarik ditujukan agar produk ayam ungkep memiliki nilai jual yang tinggi serta dapat bersaing dengan produk yang lain.

\section{Analisis Komposisi Nutrisi Produk}

Analisis komposisi produk sangat dibutuhkan untuk mengetahui kualitas ayam ungkep yang dihasilkan. Metode analisis yang dilakukan dapat dilihat pada Tabel 1 .

Tabel 1. Metode Analisis Kimia

\begin{tabular}{|c|c|c|}
\hline No & Analisis & Metode \\
\hline 1 & Kadar air & $\begin{array}{l}\text { Thermogravimetri } \\
\text { (AOAC, 2002) }\end{array}$ \\
\hline 2 & Kadar abu & $\begin{array}{l}\text { Cara Langsung (AOAC, } \\
\text { 2002) }\end{array}$ \\
\hline 3 & $\begin{array}{l}\text { Kadar } \\
\text { Protein }\end{array}$ & $\begin{array}{l}\text { Metode Kjeldahl-Mikro } \\
\text { (AOAC, 2002) }\end{array}$ \\
\hline 4 & $\begin{array}{l}\text { Kadar } \\
\text { Lemak }\end{array}$ & $\begin{array}{l}\text { Ekstraksi } \\
(\mathrm{AOAC}, 2002)\end{array}$ \\
\hline 5 & $\begin{array}{l}\text { Kadar } \\
\text { Karbohidrat }\end{array}$ & $\begin{array}{l}\text { By Difference (AOAC, } \\
2002)\end{array}$ \\
\hline
\end{tabular}

\section{Pelatihan pemasaran berbasis TI dan strategi direct selling}

Dasar dari pelatihan pemasaran ini adalah pemanfaatan TI (Teknologi Informasi) dengan maraknya jejaring sosial yang tersedia. Banyaknya bisnis online serta banyaknya pengguna jejaring sosial membuat pemasaran produk di dunia maya menjadi salah satu cara yang efektif. Pelatihan pemanfaatan jejaring sosial facebook, pembuatan blog, serta pemasangan iklan dengan menampilkan produk-produk akan sangat membantu untuk perkembangan industri rumah tangga yang ada di Desa Gembongan. Pemasaran dengan pemanfaatan TI ini sangat menguntungkan sebab produk tidak hanya dikenal disekitar lingkungan tetapi mampu dikenali oleh masyarakat luas. Pelatihan ini akan berjalan apabila warga (anggota industri rumah tangga) di Desa Gembongan mengetahui tentang bisnis online serta terampil dalam pengelolaan jejaring tersebut. Target utama pelatihan pemasaran dengan TI mitra yang memiliki industri rumah tangga ayam ungkep. Produk utama yang dipasarkan dengan TI adalah produk ayam ungkep. Materi utama pada pelatihan ini adalah blog, web developing, dan pengelolaannya. Sedangkan untuk strategi direct selling yang utamanya akan disampaikan adalah motivasi dan teknik negosiasi.

Strategi yang diterapkan untuk menjamin keberhasilan dari berbagai program pada kegiatan ini adalah peralatan yang digunakan sebagai alat pelatihan akan dihibahkan ke pengrajin mitra, sehingga tidak ada kendala lagi bagi para pengrajin. Tim pengabdian juga akan terus melakukan pendampingan sejak produksi hingga pemasaran, untuk menjamin stabilitas dan kontinuitas usaha.

\section{HASIL DAN PEMBAHASAN}

Introduksi teknologi tepat guna proses pengolahan dan penyimpanan ayam ungkep berupa mesin pencabut bulu ayam dan freezer

Seperti halnya yang telah diketahui bahwa permasalahan utama pada mitra I (peternakan Hartanto) pada kegiatan ini adalah proses pencabutan bulu ayam. Proses ini masih dilakukan secara manual. Hal inilah yang menyebabkan proses di bagian awal ini membutuhkan waktu yang cukup lama. Pada pengabdian ini tim telah mengintroduksikan teknologi tepat guna berupa mesin pencabut bulu ayam untuk mempermudah proses pencabutan bulu. Mesin ini memiliki kapasitas 4-5 ekor ayam sekali proses. Kerangka mesin dipilih dari bahan stainlessteel agar lebih awet dan tidak mengkontaminasi produk. Dengan adanya mesin ini, mitra I dapat menghemat $85 \%$ dari waktu semula untuk proses pencabutan bulu. Mesin pencabut bulu ayam dan dokumentasi penyerahan dapat dilihat pada Gambar 1 . 


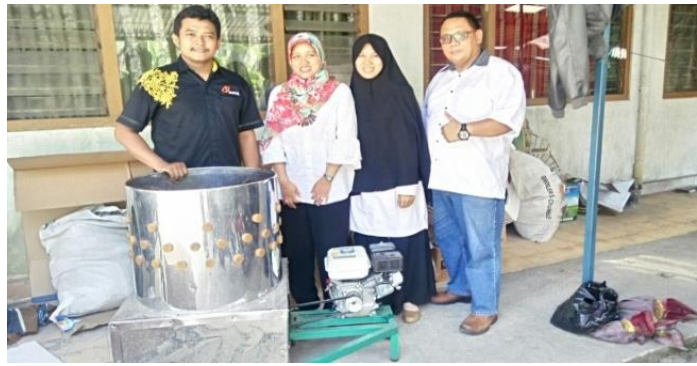

Gambar 1. Dokumentasi Penyerahan Mesin Pencabut Bulu Ayam

Pada Mitra II (IRT Ayam Ungkep Mas Haji), proses yang masih menjadi kendala adalah penyimpanan. Ayam ungkep yang dihasilkan, dituntut untuk disimpan beku agar produk memiliki umur simpan yang lebih lama. Pada mitra, freezer yang dimiliki memiliki kapasitas kecil dan dipakai bersamaan untuk menyimpan produk lain sehingga kapasitas penyimpanan ayam ungkep sangat terbatas. Melihat hal tersebut, tim pengabdian mengintroduksikan mesin freezer guna menyelesaikan permasalahan pada mitra II. Adanya freezer dengan kapasitas yang lebih besar, diharapkan dapat mendukung peningkatan kapasitas produksi yang akan direncanakan serta menghindari kontaminasi silang produk ayam ungkep dengan produk yang lain. Introduksi freezer kepada mitra II dapat dilihat pada Gambar 2.

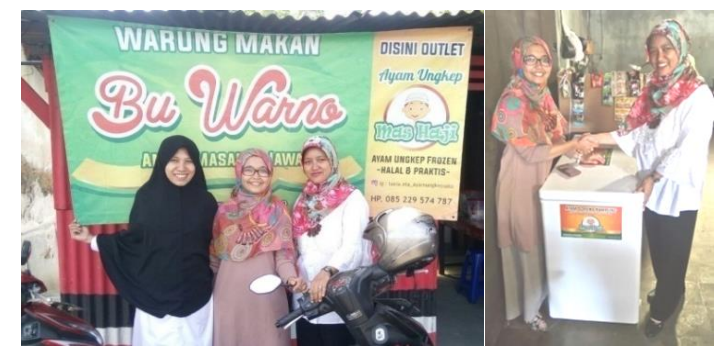

Gambar 2. Dokumentasi Penyerahan Freezer Pada Mitra II

\section{Perbaikan pengemasan produk dengan vacuum sealer dan variasi bahan pengemas}

Peralatan vacuum sealer yang dimiliki mitra II saat ini masih berkapasitas kecil dan berkemampuan menciptakan vakum yang rendah. Tidak jarang produk yang telah di vakum kembali menjadi sobek atau bocor. Hal ini tentu saja menyebabkan banyak kerugian. Pada tahap ini tim pengabdian juga mengintroduksikan mesin vacuum sealer dengan kapasitas lebih besar kepada mitra II. Dengan mesin ini, kerugian proses akibat kerusakan kemasan dapat diminalkan.

Produk ayam ungkep yang dihasilkan juga dilakukan perbaikan dengan memberikan label pada produk. Label yang diberikan diharapkan dapat meningkatkan daya tarik konsumen. Dokumentasi proses penyerahan vacuum sealer dan label kemasan ayam ungkep dapat dilihat pada Gambar 3.

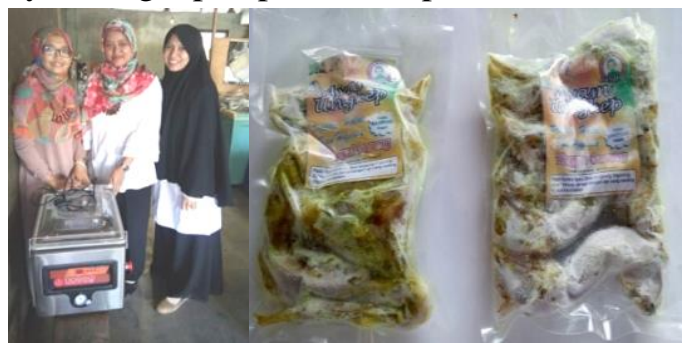

Gambar 3. Dokumentasi Penyerahan Vacuum Sealer Pada Mitra II (a) dan Kemasan Produk Ayam Ungkep yang Dihasilkan (b)

\section{Pengujian komposisi nutrisi produk}

Produk ayam ungkep yang saat ini dihasilkan, belum memiliki ijin usaha atau merk dagang yang resmi. Hal ini disebabkan salah satunya karena belum pernah dilakukannya analisis komponen kimia produk yang dihasilkan. Pada program ini, tim pengabdian juga membantu mitra untuk melakukan karakterisasi komposisi nutrisi produk ayam ungkep meliputi komposisi kimia (air, abu, lemak, protein, dan karbohidrat). Analisis kimia ditujukan untuk mengetahui komposisi gizi produk. Hasil analisis kimia dan mikrobiologi produk ayam ungkep dapat dilihat pada Tabel 2. 
Tabel 2. Hasil Analisa Kimia Produk Ayam Ungkep

\begin{tabular}{lc}
\hline \multicolumn{1}{c}{ Macam Analisa } & Hasil Analisa \\
\hline Air $(\%)$ & 79,78 \\
Abu (\%) & 1,58 \\
Lemak (\%) & 3,78 \\
Protein, fk:6,25 (\%) & 11,72 \\
Karbohidrat (\%) & 3,14 \\
\hline
\end{tabular}

Berdasarkan analisa yang dilakukan, diketahui bahwa secara kimia produk ayam ungkep yang dihasilkan mitra memiliki komposisi gizi yang baik. Kandungan protein yang tinggi $(11,72 \%)$ dan lemak yang rendah $(3,78 \%)$ baik untuk pertumbuhan dan kesehatan tubuh.

\section{Pelatihan pemasaran berbasis Teknologi} Informasi (TI) dan strategi direct selling

Pemasaran merupakan tahap akhir yang sangat penting dalam usaha pengolahan makanan. Saat ini, produk ayam ungkep yang dihasilkan oleh mitra hanya dipasarkan secara langsung ketika ada pesanan dan dititipkan di warung makan milik saudara. Hal ini tentu saja hanya menghasilkan tingkat penjualan yang rendah. Oleh karena itu, pada program ini tim pengabdian membantu mitra untuk melakukan pemasaran dengan sistem online. Untuk itulah pada akhir kegiatan ini, tim pengabdian juga juga memberikan pelatihan pemasaran berbasis TI dan strategi direct selling.

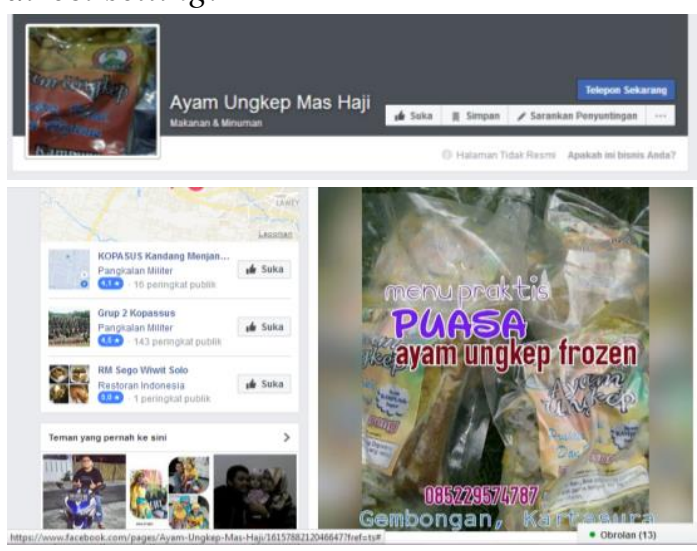

Gambar 4. Contoh Iklan di Facebook
Mitra diajarkan untuk membuat membuat iklan di media sosial meliputi facebook, whatsapp, maupun instagram. Hal ini diharapkan dapat meningkatan laju penjualan. Contoh iklan ayam ungkep di media sosial facebook dapat dilihat pada Gambar 4. Dengan adanya pemasaan secara online tersebut, terjadi peningkatan kapasitas penjualan produk ayam ungkep sebezar $35 \%$.

\section{KESIMPULAN}

Dari kegiatan pengabdian IbM ini dapat diambil kesimpulan:

1. Introduksi mesin pencabut bulu ayam dan freezer mampu meningkatkan kapasitas produksi dan penyimpanan ayam ungkep

2. Vacuum sealer dan variasi bahan pengemas ayam ungkep mampu meningkatkan efisiensi pengemasan dan meningkatkan daya tarik konsumen

3. Ayam ungkep yang dihasilkan memiliki komposisi nutrisi yang baik

4. Adanya pelatihan berbasis TI dan strategi direct selling mampu meningkatkan kapasitas penjualan produk sebesar 35\%.

\section{DAFTAR PUSTAKA}

Anonim, 2016. Sukoharjo Dalam Angka. Badan Pusat Statistik Kabupaten Sukoharjo

AOAC ( Associantion Of Official Analitycal Chemist). 2002. Official Methods of Analysis. Washington D.C

Murtidjo, B. A., 1994. Mengelola Ayam Kampung. Kanisius, Yogyakarta

Syarief, R dan Halid, H. 1993. Teknologi Penyimpanan Pangan. IPB. Bogor 